\title{
Brendan Karch, Nation and loyalty in a German-Polish borderland: Upper Silesia, 1848-1960
}

\author{
Kamusella, Tomasz
}

\begin{tabular}{|c|c|}
\hline Date of deposit & $30 / 10 / 2019$ \\
\hline Document version & Author's accepted manuscript \\
\hline Access rights & $\begin{array}{l}\text { Copyright (C) } 2019 \text { by SAGE Publications. This work has been } \\
\text { made available online in accordance with publisher policies or } \\
\text { with permission. Permission for further reuse of this content } \\
\text { should be sought from the publisher or the rights holder. This is } \\
\text { the author created accepted manuscript following peer review and } \\
\text { may differ slightly from the final published version. }\end{array}$ \\
\hline $\begin{array}{l}\text { Citation for } \\
\text { published version }\end{array}$ & $\begin{array}{l}\text { Kamusella, T. D. (2019). Brendan Karch, Nation and Loyalty in a } \\
\text { German-Polish Borderland: Upper Silesia, 1848-1960. European } \\
\text { History Quarterly, 49(4), 692-694. }\end{array}$ \\
\hline $\begin{array}{l}\text { Link to published } \\
\text { version }\end{array}$ & https://doi.org/10.1177/0265691419877354e \\
\hline
\end{tabular}

Full metadata for this item is available in St Andrews Research

Repository at: https://research-repository.st-andrews.ac.uk/

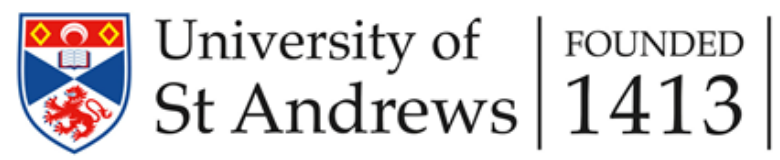


Brendan Karch, Nation and Loyalty in a German-Polish Borderland, Cambridge: Cambridge University Press and Washington DC: German Historical Institute, 2018, xv + 331, index, line-drawn maps, black and white illustrations, 9781108487108 (hbk)

When in the mid-2000s, James Bjork (Neither German nor Pole 2008) and I (Silesia and Central European Nationalisms 2007) hoped to introduce Upper Silesia to the attention of students of nationalism and Central European history, most preferred the case of Bohemia, as incisively analyzed by Jeremy King (Budweisers into Czechs and Germans 2002), Pieter Judson (Guardians of the Nation 2006), or Tara Zahra (Kidnapped Souls 2008). Certainly, the colorful Czech capital of Prague was more fun than the then drab Upper Silesian industrial basin in the grips of the socially painful de-industrialization, which swiftly followed the end of communism. Yet, historical developments in the region that falsify many established theses about nationalism, at long last, have attracted a bevy of intrepid international scholars. They are responsible for the recent bumper crop of wide-ranging monographs on various aspects of nationalism and ethnicity in modern Upper Silesia, for instance, by Tim Wilson (Frontiers of Violence Conflict and Identity in Ulster and Upper Silesia 2010), Hugo Service (Germans to Poles 2013), Anna Novikov (Shades of a Nation 2015), or Peter Polak-Springer (Recovered Territory 2018). The growing synergy of comparative and interdisciplinary research on Upper Silesia is exemplified by the edited volume Creating Nationality in Central Europe (2016) in which all the aforementioned researchers participated, including the author of the monograph under review.

Karch's work, rewardingly steeped in German and Polish archival material and secondary literature, is an important addition to this growing store of knowledge and entailed methodological insights, because - uniquely, in Anglophone literature - it focuses on interwar Germany's section of Upper Silesia. The story opens during the 1848 revolutions with a look at the region's confessionally homogenous population of Catholics (Chapter 1). At that time religious and estate difference decided about one's loyalties, not language. This changed with the rise of ethnolinguistic national movements and nation-states during the latter half of the $19^{\text {th }}$ century (Chapter 2). But most (Upper) Silesians reacted with the development of their own local and 'regional' (why not national?) identity(ies). Karch rightly concludes that industrialization does not need to lead to the creation of nations, thus, usefully falsifying Ernest Gellner's deterministic thesis to this end (56-57). However, it was the Great War, which destabilized politics and economy, eventually delegitimizing non-national polities (empires), which subsequently were replaced - under the victorious Allies' watch - with yet more ethnolinguistic nation-states across central Europe. In this process the belonging of Upper Silesia to the German Empire was questioned. Intermittent civil war (1919-1922), the 1921 plebiscite, and the 1922 division of their region forced the (Upper) Silesians to choose between the German nation-state they knew and the just founded Polish national polity. Rhetorically, this choice was posed in essentialist terms, Poles voting for Poland and Germans for Germany. No space was left for Silesians, who constituted the majority of the region's population.

The book's forte is the interwar period. Between 1922 and 1933, in the German section of the region, democracy let Silesians stick to their 'non-national' (why not own 
a/national?) choices, much to the dismay of German nationalists (Chapter 4). They got another chance to force Silesians into the national line later, but initially the remnants of the postwar international system of minorities treaties curbed this effort. Inadvertently, until 1937, this system shielded the region's Jews against the Nuremberg Laws of 1935 (Chapter 5). A variety of totalitarian policies implemented to make Silesians into indistinguishable members of the homogenous German ethnolinguistic nation (Volksgemeinschaft) worked on the surface, but in most cases led to the solidification of the Silesian identity. The continuing functional diglossia (rather than bilingualism) in German and Silesian (often interpreted as Slavic or Polish) enabled Silesians to act as Germans or Poles (and Czechs), when needed (Chapter 6). The story concludes with Poland's even more totalitarian methods of imposing Polishness on the Silesians after 1945, when the Allies granted all of Upper Silesia, alongside other German territories, to postwar Poland (Chapter 7). Incomprehensibly, the chapter covers the period until 1960, with no clear justification for this cesura, while stopping in 1950 (when the region was split into Opole and Katowice regions), or in 1956 would make more sense.

Given that in 2009 the spelling of the Silesian language was standardized, the Polishlanguage ethnonym of the Silesians, Ślązacy (2), could be replaced with the Silesianlanguage one of Ślōnzoki, while the German-language name of their Silesian language, schlonsak (3), with the Silesian term ślōnskŏ gŏdka. It is hard and laudable to divine Silesians' opposition to both intermittent Germanization and Polonization, alongside their own identificational practices and wishes, from German and Polish archival material and literature that follow the requirements of this or that national master narrative. Hence, it is surprising that Dariusz Jerczyński's extensive history of the Silesian nation written from the Silesian national perspective (Historia Narodu Śląskiego 2013, $3^{\text {rd }}$ edition) was not consulted. Karch steers away from Austrian/Czech Silesia that has been intimately intertwined with Prussian/German/Polish Silesia to this day, which prevents him from commenting on Bishop Josef Martin Nathan's administration of the Upper Silesian section of the Moravian Archdiocese (1916-1946). Famously, in defiance of the nazi administration, as a self-declared Moravian, he allowed pastoral services in Czech, Moravian, Polish or Silesian. An integrated analysis of both Upper Silesias, which promises more incisive insights into the phenomenon of non/a-nationality ('national indeterminacy'), still awaits an international scholar ready to take up to this challenge. Another extensive monograph by D Jerczyński (Józef Kożdoń (1873-1949) przywódca Śląskiej Partii Ludowej, a kwestia narodowości śląskiej na Śląsku Cieszyńskim i Opawskim w XIX $i$ XX stuleciu 2012) would be of much help in this regard, like Kevin Hannan's 1996 work Borders of Language and Identity in Teschen Silesia, mentioned by Karch. From other quibbles, it would help to reflect on the coining of the Polish neologism 'autochthon' or the total uprooting of German in Upper Silesia after 1950, and to include the Soviet share of the lands lost by Germany on map 7.1 (271), to add that it was Poland who wanted outvoters to participate in the plebiscite (138), or that unlike the nazis, Polish administration Polonized all Upper Silesia's place names without any consultations with those concerned. Last but not least, if Upper Silesia's Jews merit an entire chapter (Chapter 4), why not a section on the region's Roma? 